\title{
Carryover Effect of Imidazolinone Herbicides for Crops Following Rice
}

\author{
L. O. Santos'1, J. J. O. Pinto', L. B. Piveta' ${ }^{1}$ J. A. Noldin'², L. Galon³, \\ G. Concenço ${ }^{*}$ \\ ${ }^{1}$ Plant Health Department, Federal University of Pelotas, Capão do Leão, Brazil \\ ${ }^{2}$ Itajaí Experimental Station, Santa Catarina State Institution for Agricultural Research and Extension (Epagri), \\ Itajai, Brazil \\ ${ }^{3}$ Plant Science Department, Federal University of the Southern Border, Erechim, Brazil \\ ${ }^{4}$ Weed Science, Embrapa Western Agriculture, Dourados, Brazil \\ Email: leonardo-o-santos@hotmail.com
}

Received 3 January 2014; revised 16 February 2014; accepted 6 March 2014

Copyright (c) 2014 by authors and Scientific Research Publishing Inc.

This work is licensed under the Creative Commons Attribution International License (CC BY).

http://creativecommons.org/licenses/by/4.0/

(c) ()

\begin{abstract}
We aimed with this study to evaluate the effects of residual activity in soil of formulated mixtures of the herbicides imazethapyr + imazapic and imazapyr + imazapic on ryegrass and on rice cultivars, IRGA 424 and BRS Querencia. Two experiments were conducted under greenhouse in randomized blocks design with four replications in split-plot and split-split-plot designs, respectively for the first (E1) and second (E2) experiments. For E1, main plots allocated herbicides (imazethapyr + imazapic and imazapyr + imazapic), and subplots the doses $[(0,0.5,1.0,1.5$ and 2.0 fold the label dose of imazethapyr + imazapic $\left(1 \mathrm{~L} \cdot \mathrm{ha}^{-1}\right)$ and imazapyr + imazapic $\left(140 \mathrm{~g} \cdot \mathrm{ha}^{-1}\right)$ plus $0.5 \%$ of the adjuvant Dash ${ }^{\circledR}$ )]; for E2, sub-subplots allocated rice cultivars (BRS 424 and IRGA Querência). Phytotoxicity, plant height and shoot dry weight (E1 and E2) and plant stand (E2) were evaluated. Results showed that the annual ryegrass and rice cultivars IRGA 424 and BRS Querencia are sensitive to imazethapyr + imazapic and imazapyr + imazapic, serving as bioindicators of its residual activity in soils following Clearfield ${ }^{\circledR}$ rice. Imazapyr + imazapic, applied post-emergence in irrigated rice at doses of 1.0, 1.5 and $2.0 \times$ the label dose, present longer residual activity in soil compared to imazethapyr + imazapic for ryegrass and non-Clearfield ${ }^{\circledR}$ rice.
\end{abstract}

\section{Keywords}

Clearfield ${ }^{\circledR}$; Imidazolinones; Soil Persistence; Oryza sativa

\footnotetext{
${ }^{*}$ Corresponding author.
} 


\section{Introduction}

Weed occurrence is among the main factors affecting yield potential of rice. Red rice is highlighted as the most impacting weed for lowland rice, with losses estimated at around US\$300 ha ${ }^{-1}$ [1]. This weed species belongs to the same species as cultivated rice, so selective chemical control is not easily achieved.

The Clearfield ${ }^{\circledR}\left(\mathrm{CL}^{\circledR}\right)$ technology allows selective control of red rice in commercial rice through the use of imidazolinone herbicides in areas planted with resistant cultivars. In Brazil, herbicides recommended for this technology are Only ${ }^{\circledR}$ —imazethapyr + imazapic $75+25$ g.a.i. $\cdot \mathrm{L}^{-1}$ and Kifix ${ }^{\circledR}$-imazapic + imazapyr $525+175$ $\mathrm{g} \cdot \mathrm{kg}^{-1}[2]$.

Among the main features of this group of herbicides, the residual activity in soil is highlighted [3], and its persistence in soil depends on several environmental and edaphic properties, being desirable or not, depending on the situation. Persistence is positive when it results in longer weed suppression [4]; it is undesirable, however, when it results in injury to crops planted in succession or rotation, or when there is risk for these residues to cause environmental contamination.

Non-tolerant species may be compromised if the minimal interval between application of the herbicide and planting in rotation is not observed [5]. In the US, where the $\mathrm{CL}^{\circledR}$ technology was developed, it is recommended the use of imazethapyr for two consecutive years, leaving the soil undisturbed for at least one year. Although studies carried out in Brazil state that the same recommendation should be used, many farmers use the technology for more than two consecutive years [6]. In temperate climate regions of Southern Brazil, ryegrass is usually planted in lowlands, in winter, following rice, and there are complains about carryover effects on ryegrass [7].

Damage to crops in succession to rice is variable depending on several factors, and distinct injury levels due to the residual activity of imazethapyr + imazapic or imazapyr + imazapic were already reported on rice, alfalfa, cotton, oats, rye, potatoes, sugar beet, canola, onions, pea, sunflower, flax, melon, maize, mustard, pepper, cabbage, sorghum, wheat, tomatoes, vetch, white clover, birdsfoot trefoil and tall fescue [8]-[11].

We aimed with this study to evaluate the effects of soil residual activity of the formulated mixture of imazethapyr + imazapic and imazapyr + imazapic, both on annual ryegrass and non-CL ${ }^{\circledR}$ rice cultivars IRGA 424 and BRS Querencia.

\section{Material and Methods}

Two experiments were conducted in a greenhouse, using rotation/succession involving $C L^{\circledR}$ rice, ryegrass and conventional rice. The first phase started in September 2009 by planting the cultivar Puita Inta CL $^{\circledR}$ followed by application of herbicides at increasing doses. The trial was installed in randomized blocks design in split-plot scheme with four replications. Main plots allocated herbicides (imazethapyr + imazapic and imazapic + imazapyr) and subplots the doses [(0, 0.5, 1.0, 1.5 and 2.0 fold the label dose of imazethapyr + imazapic $\left(1 \mathrm{~L} \cdot \mathrm{ha}^{-1}\right)$ and imazapic + imazapyr $\left(140 \mathrm{~g} \cdot \mathrm{ha}^{-1}\right)$ plus $0.5 \%$ of the recommended adjuvant Dash $\left.{ }^{\circledR}\right)$ ]. Plots consisted of polyethylene boxes ( $60 \mathrm{~cm} \times 40 \mathrm{~cm}$, with $20 \mathrm{~cm}$ height), each containing $36 \mathrm{~kg}$ of dry Haplic Planossoil, Albaqualf [12]. Herbicides were applied on $\mathrm{CL}^{\circledR}$ rice in post-emergence when crop plants were at the 4 leaf stage by using a $\mathrm{CO}_{2}$ pressurized backpack sprayer, equipped with spray nozzles type 110.02 , delivering $150 \mathrm{~L}^{-\mathrm{ha}^{-1}}$ of herbicide solution. After rice harvest, soil was left to rest with no irrigation until the time of ryegrass planting. The first experiment (E1) continued with planting $40 \mathrm{~kg} \cdot \mathrm{ha}^{-1}$ of ryegrass seeds in all experimental units on June 16, 2010. Emergence occurred ten days after planting. Phytotoxicity was evaluated 20, 31 and 40 days after plant emergence (DAE), being the absence of phytotoxicity considered as zero, and complete plant death as $100 \%$, adapted from [2]. Plant height (cm) was measured 24, 34 and 40 DAE with a ruler, at the main stem from soil surface to the tip of the last fully expanded leaf; shoot dry mass (SDM) was evaluated 40 DAE by cutting plants at ground level and drying in forced air oven at $60^{\circ} \mathrm{C}$. Data was analyzed for normality by Shapiro-Wilk test and variance homogeneity by Hartley test being subsequently subjected to analysis of variance by the F-test. When significant, herbicide effects were analyzed by Fischer's LSD test and dose effects by non-linear regression model represented by Equation (1) for phytotoxicity and Equation (2) for plant height and SDM.

$$
\bar{Y}=a\left(1-e^{-b x}\right)
$$

where: $a=$ maximum estimated value; $b=$ curve slope; $x=$ dose of the herbicides imazethapyr + imazapic $\left(\mathrm{L} \cdot \mathrm{ha}{ }^{-1}\right)$ or imazapyr + imazapic $\left(\mathrm{g} \cdot \mathrm{ha}{ }^{-1}\right) ; e=$ constant;

$$
\bar{Y}=a \cdot e^{-b x}
$$


where: $a$ = maximum estimated value; $b=$ curve slope; $x=$ dose of the herbicides imazethapyr + imazapic $\left(\mathrm{L} \cdot \mathrm{ha}^{-1}\right)$ or imazapyr + imazapic $\left(\mathrm{g} \cdot \mathrm{ha}^{-1}\right) ; e=$ constant. All tests were conducted at $5 \%$ probability. The choice for a model to explain the data was based on the statistical significance (F-test), on the determination coefficient $\left(\mathrm{R}^{2}\right)$ and on the biological significance of the model, according to Adati et al. [13], with minor adaptations.

After removal of ryegrass, the second experiment was installed (E2) following the same design already established in the first experiment. Treatments were arranged in split-split plot design being the main plots attributed to the herbicides applied in $\mathrm{CL}^{\circledR}$ rice at E1 before planting ryegrass (imazethapyr + imazapic and imazapic + imazapyr), subplots to doses, and the sub-subplots to non-CL ${ }^{\circledR}$ rice cultivars (IRGA 424 and BRS Querencia). The layout of the plots (set of five boxes) and subplots (polyethylene box) remained identical to E1, only with the addition of sub-subplots. Variables were phytotoxicity 07, 14, 21 and 31 DAE; plant stand 20 days after planting (DAP), plant height and shoot dry mass 40 DAE. Phytotoxicity, plant height and SDM were evaluated identically to that described in the first experiment, and data was analyzed in the same way.

\section{Results and Discussion}

There was interaction between herbicides and doses for all variables in E1 (Table 1, Figures 1 and 2). In all three phytotoxicity assessments, by comparing herbicides in the same dose, there were significant differences only under application of 0.5 and $1.0 \times$ the recommended dose at 20 and 31 days after emergence, respectively (Table 1).

Both imazethapyr + imazapic and imazapyr + imazapic showed increased residual activity as dose was increased (Figures 1(A)-(C)). Imazethapyr + imazapic, 20 DAE, indicated correlation between dose applied in $\mathrm{CL}^{\circledR}$ rice and intensity of symptoms in ryegrass planted in succession, and at doses of 0.65 and 1.65 -fold the label dose, symptoms averaged 53\% and 89\%, respectively. Imazapyr + imazapic, at the same doses, averaged 63\% and $93 \%$ toxicity, respectively (Figure 1 ).

For the evaluation performed 31 DAE both herbicides showed similar behavior, and phytotoxicity caused by both imazethapyr + imazapic and imazapyr + imazapic at doses of 0.65, 1.65 and 2.0-fold the label dose, were about 58\%, 90\% and 95\%, respectively (Figure 1(B)). At 40 DAE, however, it was found that imazethapyr + imazapic showed higher residual effect at the lower doses tested compared to imazapyr + imazapic, which in turn promoted the highest phytotoxicity at usual doses (Figure $1(C)$ ). These results are similar to the observed for other studies involving non CL species planted after $C L^{\circledR}$ rice [9] [10] [14].

Similar behavior was also observed for plant height. In the evaluation performed 24 DAE there were differences in residual activity between herbicides only at doses of 1.0 and $1.5 \times$ the label dose. After 34 DAE there was difference only at the label dose (1.0) and 40 DAE in the lowest (0.5-fold) and highest doses (2.0-fold) differences were observed (Table 1). For the effect of doses, for both herbicides there was growth reduction as dose was increased (Figures 2(A)-(C)). At 34 DAE, results were similar to the previous evaluation (Figure 2(B)). At 40 DAE, the exponential values were similar for both models, and the maximum damage was 7.1 and $6.9 \mathrm{~cm}$, at 2.0-fold the label dose, for imazethapyr + imazapic and imazapyr + imazapic, respectively (Figure 2(C)).

Similar results were observed by Pinto et al. [7] [15], who found that ryegrass and sorghum plant height were reduced by 17.9 and $11.2 \mathrm{~cm}$, respectively, due to the residual activity of imazethapyr + imazapic in dose of 100 $\mathrm{g} \cdot \mathrm{ha}^{-1}$. Similar behavior was observed in maize, cucumber, radish and tomato, where the residual effect of 20 $\mathrm{mg} \cdot \mathrm{m}^{-2}$ of the commercial mixture of imazethapyr + imazapic caused reductions of about $35 \%, 77 \%$, $90 \%$ and $100 \%$ in plant height, respectively for the species [16].

SDM results were in accordance with phytotoxicity and plant height. The difference in residual activity between herbicides was observed only at 1.5-fold the label dose (Table 1); both herbicides persist in soil with residual activity, but with varying intensity depending on dose. In this context, the residue of imazapyr + imazapic decreased by $72 \%$ and $92 \%$ the SDM, respectively for 1.0 and 2.0-fold the label dose, compared to the untreated plot (Figure 2(D)). Pinto et al. [7] report that residues from application of $100 \mathrm{~g} \cdot \mathrm{ha}^{-1}$ of imazethapyr + imazapic in the previous crop, reduced ryegrass SDM by 31.6\%. When this dose was increased in $50 \mathrm{~g} \cdot \mathrm{ha}^{-1}$, ryegrass SDM reductions averaged $0.9 \mathrm{t}^{\mathrm{h}} \mathrm{ha}^{-1}$. Our results, however, are not in accordance with Villa et al. [17], who observed no changes in SDM of ryegrass planted after $\mathrm{CL}^{\circledR}$ rice with application of imazethapyr + imazapic.

In E2 it was also observed interaction herbicide $\mathrm{x}$ dose for phytotoxicity, plant stand, and SDM (Table 2, Figures 3 and 4 ) and variety $\times$ dose only for SDM and plant height (Table 3 and Figure 5). For phytotoxicity 07 DAE, differences were observed between herbicides in doses of 1.0 and $1.5 \times$ the recommended (label) dose. 
Table 1. Phytotoxicity $(\%)$, height $(\mathrm{cm})$ and shoot dry mass $\left(\mathrm{g} \cdot \mathrm{box}^{-1}\right)$ of ryegrass as a function of the residual activity herbicides, evaluated in distinct days after emergence (DAE).

\begin{tabular}{|c|c|c|}
\hline \multirow{2}{*}{ Dose $^{a}$} & \multicolumn{2}{|c|}{ Herbicides } \\
\hline & imazethapyr + imazapic & imazapyr + imazapic \\
\hline \multicolumn{3}{|c|}{ Phytotoxicity (\%) 20 DAE } \\
\hline 0.0 & $00.00^{\text {ns }}$ & 00.00 \\
\hline 0.5 & $40.00^{*}$ & 56.67 \\
\hline 1.0 & $75.00^{\mathrm{ns}}$ & 75.00 \\
\hline 1.5 & $78.75^{\mathrm{ns}}$ & 87.50 \\
\hline 2.0 & $97.75^{\text {ns }}$ & 98.50 \\
\hline \multicolumn{3}{|c|}{ Phytotoxicity (\%) 31 DAE } \\
\hline 0.0 & $00.00^{\mathrm{ns}}$ & 00.00 \\
\hline 0.5 & $52.50^{\text {ns }}$ & 67.50 \\
\hline 1.0 & $70.00^{*}$ & 60.00 \\
\hline 1.5 & $83.33^{\text {ns }}$ & 88.75 \\
\hline 2.0 & $97.75^{\mathrm{ns}}$ & 98.50 \\
\hline \multicolumn{3}{|c|}{ Phytotoxicity (\%) 40 DAE } \\
\hline 0.0 & $0.00^{\mathrm{ns}}$ & 0.00 \\
\hline 0.5 & $45.00^{\text {ns }}$ & 25.00 \\
\hline 1.0 & $60.00^{\text {ns }}$ & 63.33 \\
\hline 1.5 & $92.67^{\mathrm{ns}}$ & 93.33 \\
\hline 2.0 & $99.50^{\text {ns }}$ & 99.75 \\
\hline \multicolumn{3}{|c|}{ Plant height (cm) 24 DAE } \\
\hline 0.0 & $19.73^{\text {ns }}$ & 19.73 \\
\hline 0.5 & $18.40^{\text {ns }}$ & 12.95 \\
\hline 1.0 & $17.17^{*}$ & 10.70 \\
\hline 1.5 & $11.67^{*}$ & 08.35 \\
\hline 2.0 & $03.20^{\text {ns }}$ & 03.08 \\
\hline \multicolumn{3}{|c|}{ Plant height (cm) 34 DAE } \\
\hline 0.0 & $25.25^{\text {ns }}$ & 25.25 \\
\hline 0.5 & $19.13^{\text {ns }}$ & 16.07 \\
\hline 1.0 & $17.00^{*}$ & 11.80 \\
\hline 1.5 & $08.00^{\mathrm{ns}}$ & 07.82 \\
\hline 2.0 & $02.10^{\text {ns }}$ & 02.57 \\
\hline
\end{tabular}




\section{Continued}

\begin{tabular}{lll}
\hline & \multicolumn{1}{c}{ Plant height $(\mathbf{c m}) \mathbf{4 0}$ DAE } & 27.70 \\
0.0 & $26.93^{\mathrm{ns}}$ & 11.70 \\
0.5 & $21.60^{*}$ & 20.47 \\
1.0 & $19.67^{\mathrm{ns}}$ & 09.67 \\
1.5 & $08.83^{\mathrm{ns}}$ & 03.12 \\
2.0 & $01.98^{*}$ & \\
& ${\left.\text { Shoot dry mass-SDM (g.box }{ }^{-1}\right) \mathbf{4 0} \text { DAE }}^{\mathrm{n}}$ & 11.34 \\
0.0 & $11.34^{\mathrm{ns}}$ & 07.25 \\
1.0 & $09.62^{\mathrm{ns}}$ & 04.35 \\
1.5 & $04.37^{\mathrm{ns}}$ & 00.16 \\
2.0 & $02.08^{*}$ & 00.00 \\
\hline
\end{tabular}

a $/ x$ the label dose of imazethapyr + imazapic $\left(1 \mathrm{~L} \cdot \mathrm{ha}^{-1}\right)$ and imazapyr + imazapic $\left(140 \mathrm{~g} \cdot \mathrm{ha}^{-1}\right){ }^{*}{ }^{*}$ Significant difference, by Fischer-LSD test $(p \leq 0.05)$ comparing herbicides in each dose.

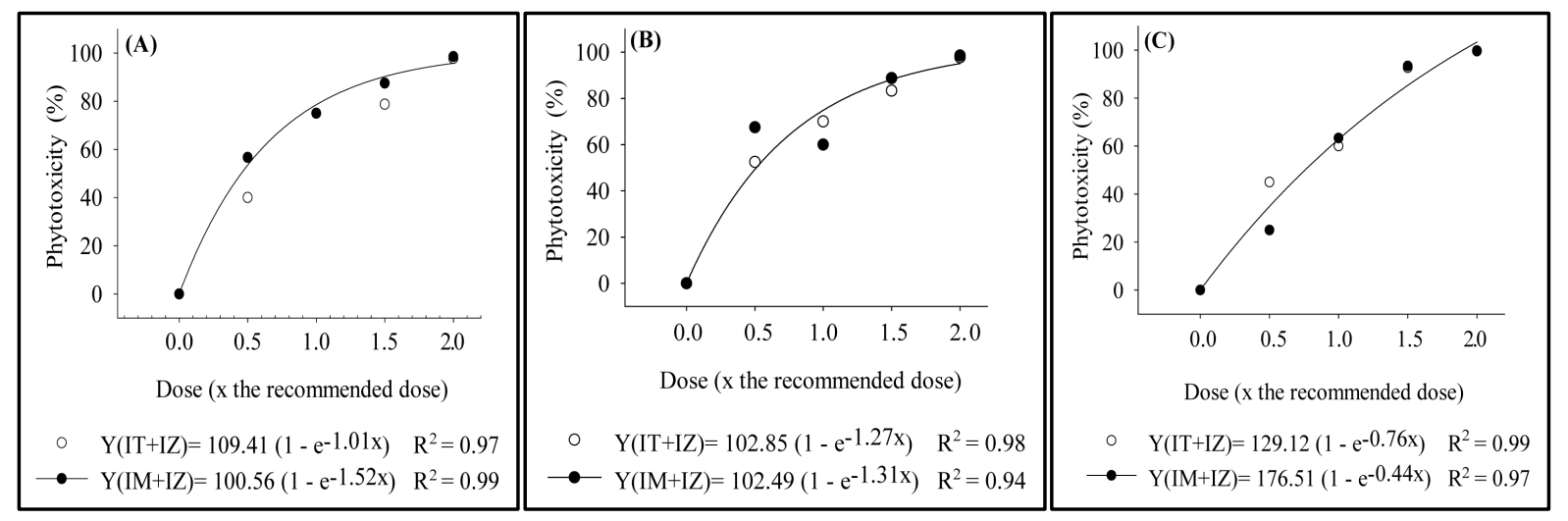

Figure 1. Phytotoxicity to ryegrass (\%) as a function of residual activity of imazethapyr + imazapic (IT + IZ) $\left(1 \mathrm{~L} \cdot \mathrm{ha}^{-1}\right)$ and imazapyr + imazapic (IM + IZ) $\left(140 \mathrm{~g} \cdot h \mathrm{a}^{-1}\right) 20$ (A), 31 (B) and 40 (C) days after emergence (DAE).

At 14 DAE, only at the label dose of 1.0×, were differences observed between herbicides; 21 DAE, however, residual effect of herbicides differed in doses of $0.5,1.0$ and $1.5 \times$ the label dose. At 31 DAE, there were no differences among herbicides for doses (Table 2).

Results demonstrate that phytotoxicity increased with dose for all periods, and the lowest phytotoxicity levels were observed 07 DAE for both herbicides. The maximum phytotoxicity for both imazethapyr + imazapic and imazapyr + imazapic was found at the highest dose $(2 \times)$, reaching about 99\% (Figures 3(A)-(D)). In studies carried out after applying imazethapyr + imazapic, it was also observed toxicity in rice cV. BR IRGA 409, IRGA 417 and BRS 7 due to its residual effect in soil at the recommended dose after three growing seasons using Clearfield $^{\circledR}$ rice [6]. Symptoms increase with entry of water in the paddy, which increases herbicide availability [18].

For rice plant stand, there were differences between the residual activity of herbicides only at 1.0 and $1.5 \times$ the label dose (Table 2). Imazethapyr + imazapic proved to be less persistent, favoring higher plant stand even at higher doses (Figure 4).

These results are in accordance to Avila et al. [6], which reported that residual activity of imazethapyr + imazapic in soil did not affect plant stand for rice varieties BR IRGA 409, IRGA 417 and BRS 7. Marchesan et al. [19], however, observed average reduction of 37\% in plant stand of IRGA 417 due to residual effect of imazethapyr + imazapic. 

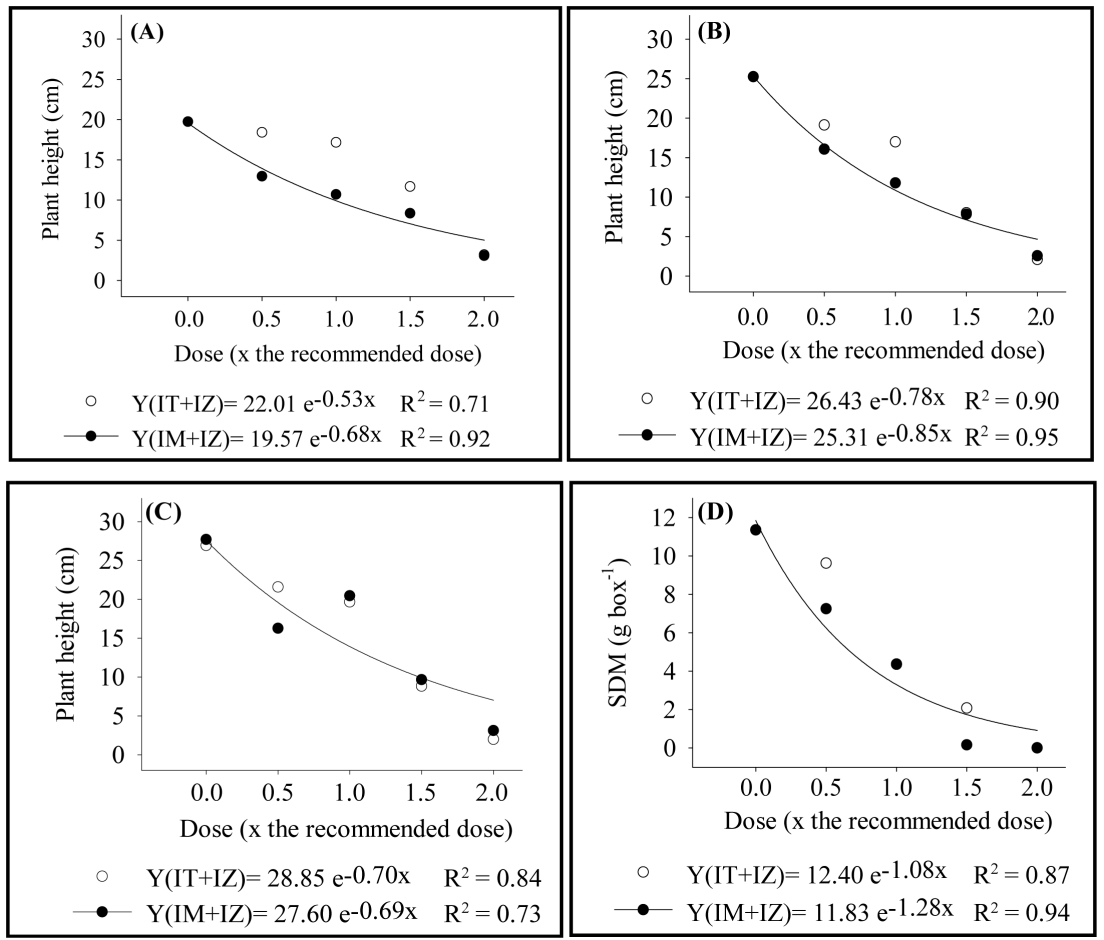

Figure 2. Ryegrass plant height (cm) 24 (A), 34 (B) and 40 (C) days after emergence (DAE) and shoot dry mass (SDM-g.box $\left.{ }^{-1}\right) 40$ DAE (D) as a function of the residual activity of imazethapyr + imazapic (IT + IZ) $\left(1 \mathrm{~L} \cdot \mathrm{ha}^{-1}\right)$ and imazapyr + imazapic (IM + IZ) $\left(140 \mathrm{~g} \cdot \mathrm{ha}^{-1}\right)$.
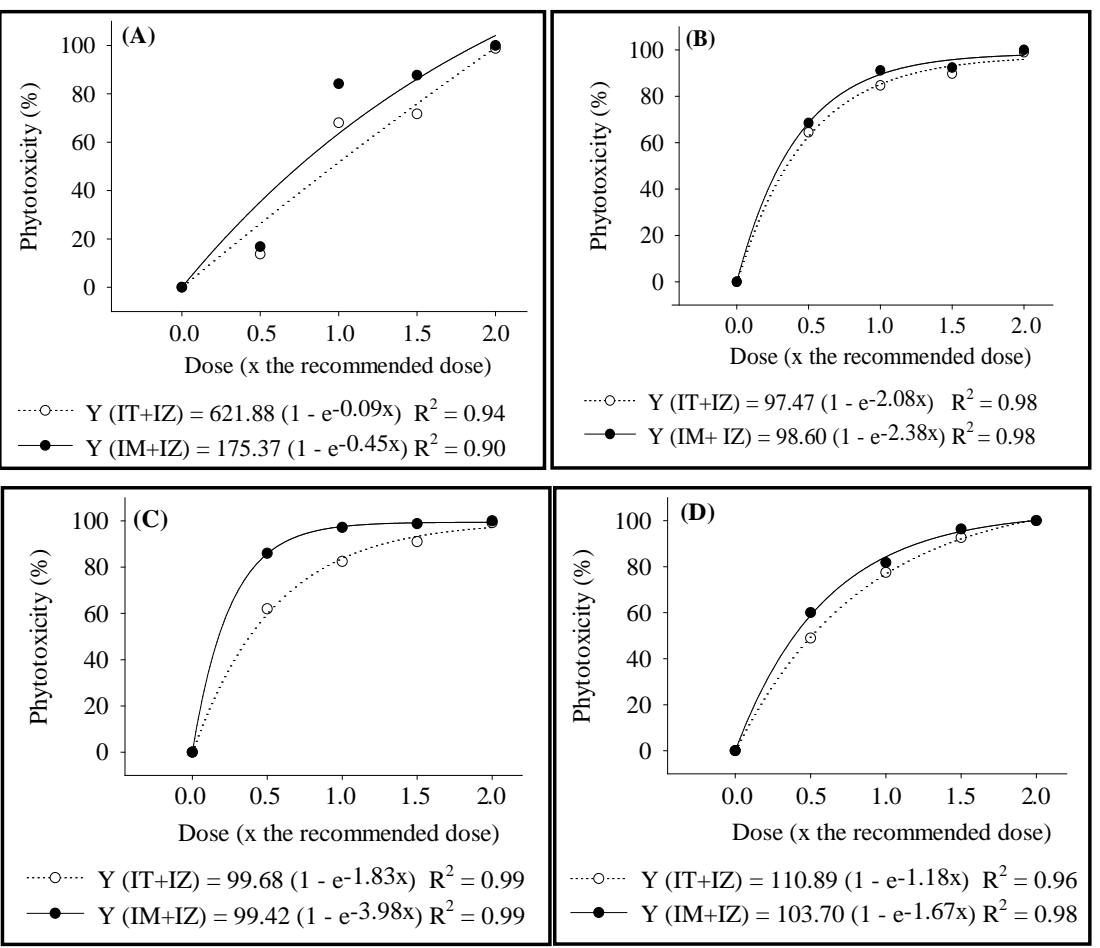

Figure 3. Phytotoxicity to rice (\%) as a function of residual activity of imazethapyr + imazapic (IT + IZ) $\left(1 \mathrm{~L} \cdot h a^{-1}\right)$ and imazapyr + imazapic (IM + IZ) $\left(140 \mathrm{~g} \cdot \mathrm{ha}^{-1}\right) 07$ (A), 14 (B), 21 (C) e 31 (D) days after emergence (DAE). 
Table 2. Phytotoxicity (\%) 07, 14, 21 and 31 days after emergence (DAE), plant stand 20 days after planting (DAP) and shoot dry mass (SDM-g box $^{-1}$ ) $40 \mathrm{DAE}$ of rice plants as a function of the residual activity of imazethapyr + imazapic and imazapyr + imazapic.

\begin{tabular}{|c|c|c|}
\hline \multirow{2}{*}{ Dose $^{a}$} & \multicolumn{2}{|c|}{ Herbicides } \\
\hline & imazethapyr + imazapic & imazapyr + imazapic \\
\hline \multicolumn{3}{|c|}{ Phytotoxicity (\%) to 07 DAE } \\
\hline 0.0 & $00.00^{\mathrm{ns}}$ & 00.00 \\
\hline 0.5 & $13.75^{\mathrm{ns}}$ & 16.79 \\
\hline 1.0 & $68.00^{*}$ & 84.17 \\
\hline 1.5 & $71.67^{*}$ & 87.67 \\
\hline 2.0 & $98.75^{\mathrm{ns}}$ & 100.00 \\
\hline \multicolumn{3}{|c|}{ Phytotoxicity (\%) to 14 DAE } \\
\hline 0.0 & $00.00^{\mathrm{ns}}$ & 00.00 \\
\hline 0.5 & $64.50^{\text {ns }}$ & 68.50 \\
\hline 1.0 & $84.71^{*}$ & 91.17 \\
\hline 1.5 & $89.75^{\mathrm{ns}}$ & 92.37 \\
\hline 2.0 & $99.00^{\mathrm{ns}}$ & 100.00 \\
\hline \multicolumn{3}{|c|}{ Phytotoxicity (\%) to 21 DAE } \\
\hline 0.0 & $00.00^{\mathrm{ns}}$ & 00.00 \\
\hline 0.5 & $62.00^{*}$ & 86.00 \\
\hline 1.0 & $82.50^{*}$ & 97.17 \\
\hline 1.5 & $91.00^{*}$ & 98.75 \\
\hline 2.0 & $99.25^{\mathrm{ns}}$ & 100.00 \\
\hline \multicolumn{3}{|c|}{ Phytotoxicity (\%) to 31 DAE } \\
\hline 0.0 & $00.00^{\text {ns }}$ & 00.00 \\
\hline 0.5 & $48.93^{\mathrm{ns}}$ & 60.00 \\
\hline 1.0 & $77.50^{\mathrm{ns}}$ & 81.75 \\
\hline 1.5 & $92.62^{\mathrm{ns}}$ & 96.37 \\
\hline 2.0 & $100.00^{\mathrm{ns}}$ & 100.00 \\
\hline \multicolumn{3}{|c|}{ Plant stand to 20 DAP } \\
\hline 0.0 & $20.62^{\mathrm{ns}}$ & 20.62 \\
\hline 0.5 & $17.62^{\mathrm{ns}}$ & 16.87 \\
\hline 1.0 & $16.25^{*}$ & 12.00 \\
\hline 1.5 & $12.00^{*}$ & 05.17 \\
\hline 2.0 & $00.00^{\text {ns }}$ & 00.00 \\
\hline \multicolumn{3}{|c|}{ Shoot dry mass-SDM (g.box $\left.{ }^{-1}\right) 40$ DAE } \\
\hline 0.0 & $43.01^{\mathrm{ns}}$ & 43.01 \\
\hline 0.5 & $30.11^{\mathrm{ns}}$ & 26.59 \\
\hline 1.0 & $25.69^{*}$ & 14.84 \\
\hline 1.5 & $00.80^{\mathrm{ns}}$ & 01.24 \\
\hline 2.0 & $00.00^{\mathrm{ns}}$ & 00.00 \\
\hline
\end{tabular}

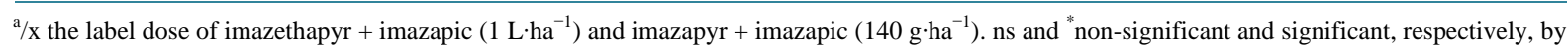
the Fischer-LSD test $(p \leq 0.05)$ comparing herbicides in each dose. 
Table 3. Rice cultivars shoot dry mass (SDM-g·box ${ }^{-1}$ ) and plant height IRGA 424 e BRS Querência as a function of residual activity of imazethapyr + imazapic and imazapyr + imazapic reviews to 40 days after emergence of plants (DAE).

\begin{tabular}{|c|c|c|}
\hline \multirow{2}{*}{ Dose $^{a}$} & \multicolumn{2}{|c|}{ Cultivars } \\
\hline & IRGA 424 & BRS Querência \\
\hline \multicolumn{3}{|c|}{ Shoot dry mass-SDM $\left(g \cdot b^{-1} x^{-1}\right) 40$ DAE } \\
\hline 0.0 & $37.37^{*}$ & 48.66 \\
\hline 0.5 & $28.53^{\text {ns }}$ & 28.17 \\
\hline 1.0 & $16.80^{\text {ns }}$ & 20.80 \\
\hline 1.5 & $00.81^{\text {ns }}$ & 01.10 \\
\hline 2.0 & $00.00^{\mathrm{ns}}$ & 00.00 \\
\hline \multicolumn{3}{|c|}{ Plant height (cm) to 40 DAE } \\
\hline 0.0 & $66.20^{*}$ & 79.00 \\
\hline 0.5 & $60.77^{*}$ & 73.21 \\
\hline 1.0 & $55.66^{\text {ns }}$ & 67.23 \\
\hline 1.5 & $18.65^{\text {ns }}$ & 22.60 \\
\hline 2.0 & $00.00^{\text {ns }}$ & 00.00 \\
\hline
\end{tabular}

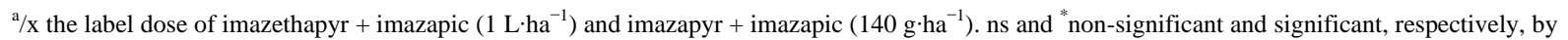
the Fischer-LSD test $(p \leq 0.05)$ comparing cultivars in each dose.

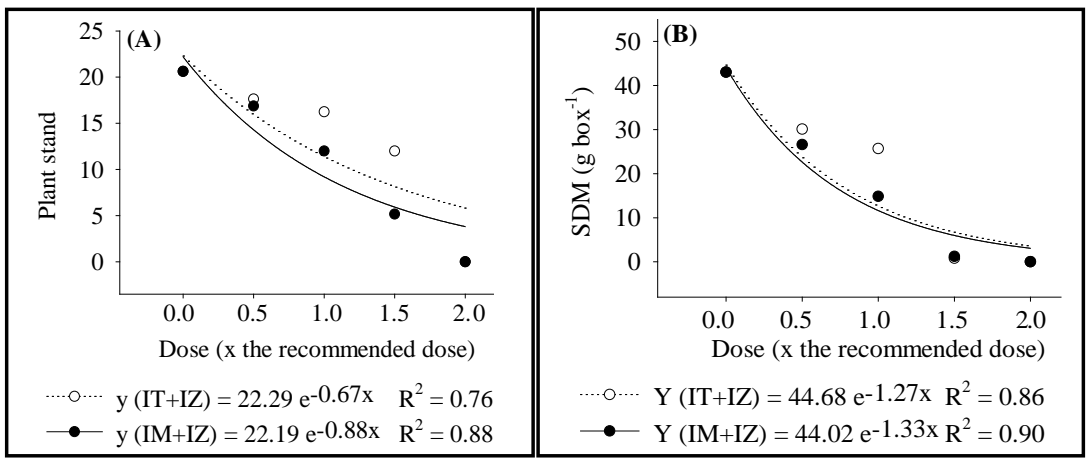

Figure 4. Plant stand of rice to 20 days after sowing (DAS) (A) e soot dry mass $\left(\mathrm{SDM}-\mathrm{g} \cdot \mathrm{box}^{-1}\right.$ ) of plants rice to 40 days after emergence of plants (DAE) (B) as a function of the residual activity of imazethapyr + imazapic (IT + IZ) $\left(1 \mathrm{~L}^{\circ} \mathrm{ha}^{-1}\right)$ and imazapyr + imazapic (IM + IZ) $\left(140 \mathrm{~g} \cdot \mathrm{ha}^{-1}\right)$.

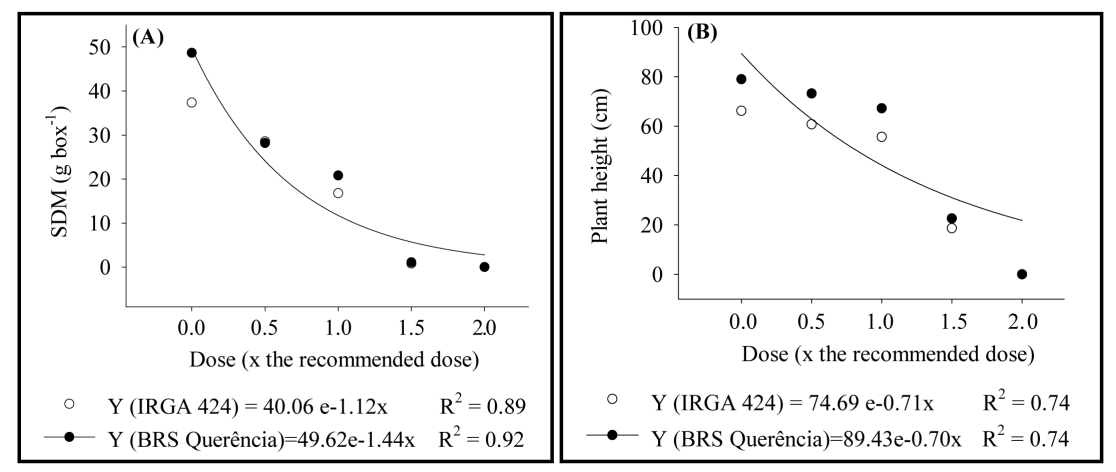

Figure 5. Rice cultivars shoot dry mass $\left(\mathrm{SDM}-\mathrm{g} \cdot \mathrm{box}^{-1}\right)$ - A and plant height $(\mathrm{cm})$ B of plants IRGA 424 and BRS Querência to 40 days after emergence (DAE) of rice plants as a function of the residual activity of imazethapyr + imazapic $\left(1 \mathrm{~L}^{\prime} \mathrm{ha}^{-1}\right)$ e imazapyr + imazapic (140 g·ha ${ }^{-1}$ ). 
The difference in residual activity between herbicides for SDM was only observed at $1.0 \times$ the label dose (Table 2). Curve slopes related to SDM (Figure 4(B)) showed residual effect from both imazethapyr + imazapic and imazapyr + imazapic on rice plants compared to the control $(0.0 \times)$ for all doses. When non-tolerant rice was grown in soil with 1.0, 1.5 and 2.0 $\times$ the label dose, SDM accumulation was reduced in $72 \%$, $85 \%$ and $92 \%$ for imazethapyr + imazapic, and 73\%, 86\% and 93\% for imazapyr + imazapic. In this context, Pinto et al. [10] reported imazethapyr + imazapic at doses of 100, 150 and $200 \mathrm{~g} \cdot \mathrm{ha}^{-1}$ decreased, respectively, SDM in 76\%, 95\% and 96\% for IRGA 417.

For SDM there was no interaction between cultivar and dose (Table 3 and Figure 5); IRGA 424 and BRS Querencia differed only at the control treatment (Table 3). Residues from the label dose (1.0×) reduced by 67 and 76\% SDM of IRGA 424 and BRS Querencia, respectively (Figure 5). Similar results were observed under

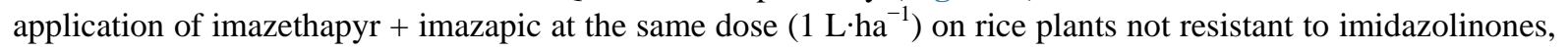
where the residual effect resulted in 76\% SDM reduction for IRGA 417 [10]. Research reports that the residual activity of imazethapyr + imazapic resulted in SDM reduction for 9 crops among 11 tested [8].

Rice plant height, similar to SDM, was also reduced (Table 3); this difference between rice cultivars was expected, since smaller plant height is characteristic of IRGA 424 compared to BRS Querencia [2]. Both cultivars were reduced in height as dose was increased, with reductions reaching $51 \%$ and $50 \%$ at the label dose, while twice the dose (2.0×) reduced plant height in 76\% and 75\% for IRGA 424 and BRS Querencia, respectively, compared to the control treatment (Figure 5(B)). Pinto et al. [10] found that residues of $1 \mathrm{~g} \cdot \mathrm{ha}^{-1}$ of imazethapyr $^{-}$

+ imazapic reduced by $0.18 \mathrm{~cm}$ rice plant height.

In both experiments, differences between imazethapyr + imazapic and imazapyr + imazapic, may possibly be related to the components of the two mixtures. Imazapyr, imazapic and imazethapyr present differential chemical properties as Kow, pKa and half-life [20], thus residual effects in soil differ and injury levels to susceptible crops following Clearfield ${ }^{\circledR}$ rice will also be distinct.

\section{Conclusions}

Annual ryegrass and rice IRGA cv. 424 and BRS Querencia (non-Clearfield ${ }^{\circledR}$ ) are susceptible to commercial mixtures of both imazethapyr + imazapic and imazapyr + imazapic, serving as bioindicators of its residues in soils previously planted with Clearfield ${ }^{\circledR}$ rice.

Imazethapyr + imazapic and imazapyr + imazapic at doses of $1.0 \times, 1.5 \times$ and $2.0 \times$ applied post-emergence to rice, remain sufficiently active in soil to reduce plant height and shoot dry mass of both ryegrass planted in succession and non-tolerant rice planted in the next cropping season.

Imazapyr + imazapic present longer residual activity in soil with stronger effects on ryegrass and non-tolerant rice, compared to imazethapyr + imazapic, at equivalent doses.

\section{Acknowledgements}

The authors would like to thank CNPq—National Council for Scientific and Technological Development, for the financial support granted for this research.

\section{References}

[1] Burgos, N.R., Norsworthy, K.J., Scott, R.C. and Smith, K.L. (2008) Red Rice (Oryza sativa) Status after 5 Years of Imidazolinone-Resistant Rice Technology in Arkansas. Weed Technology, 22, 200-208. http://dx.doi.org/10.1614/WT-07-075.1

[2] Sosbai-Sociedade Sul-Brasileira de Arroz Irrigado (2012) Arroz irrigado, recomendações técnicas da pesquisa para o Sul do Brasil. SOSBAI, Itajaí/SC, 179 p.

[3] Loux, M.M. and Reese, K.D. (1993) Effect of Soil Type and pH on Persistence and Carryover of Imidazolinones Herbicides. Weed Technology, 7, 452-458.

[4] Gazziero, D.L.P., Karan, D., Voll, E. and Ulbrich, A. (1997) Persistence of Imazaquin and Imazethapyr in the Soil, and Their Effects on Corn and Cucumber. Planta Daninha, 15, 162-168.

[5] Williams, B.J., Strahan, R. and Eric, P.W. (2002) Weed Management Systems for Clearfield Rice. Louisiana Agriculture Magazine, 45, 16-17.

[6] Avila, L.A., Teló, G.M., Ferreira, R.B., Marchesan, E., Machado, S.L.O., Rossato, T.L., Cezimbra, D.M. and Rigão Jr., G. (2010) Non-Tolerant Rice Production after Using the Clearfield ${ }^{\mathrm{TM}}$ Rice System. Planta Daninha, 28, 123-129. 
http://dx.doi.org/10.1590/S0100-83582010000100015

[7] Pinto, J.J.O., Noldin, J.A., Rosenthal, M.D., Pinho, C.F., Rossi, F.V., Machado, A., Piveta, L. and Galon, L. (2009) Residual Activity of (Imazethapyr + Imazapic) on Ryegrass (Lolium multiflorum), Following Clearfield ${ }^{\circledR}$ Rice. Planta Daninha, 27, 609-619. http://dx.doi.org/10.1590/S0100-83582009000300023

[8] Alister, C. and Kogan, M. (2005) Efficacy of Imidazolinone Herbicides Applied to Imidazolinone-Resistant Maize and Their Carryover Effect on Rotational Crops. Crop Protection, 24, 375-379. http://dx.doi.org/10.1016/j.cropro.2004.09.011

[9] Süzer, S. and Büyük, H. (2010) Residual Effects of Spraying Imidazolinone-Family Herbicides on Clearfield ${ }^{\circledR}$ Sunflower Production from the Point of View of Crop Rotation. Helia, 33, 25-36. http://dx.doi.org/10.2298/HEL1052025S

[10] Pinto, J.J.O., Noldin, J.A., Sousa, C.P., Agostinetto, D., Piveta, L. and Donida, A. (2011) Residual Soil Activity of Imazethapyr + Imazapic to Rice Planted in Rotation after Clearfield Rice ${ }^{\circledR}$. Planta Daninha, 29, 205-216. http://dx.doi.org/10.1590/S0100-83582011000100023

[11] Concenco, G., Aspiazu, I., Ferreira, E.A., Galon, L. and Silva, A.F. (2012) Physiology of Crops and Weeds under Biotic and Abiotic Stresses. In: Najafpour, M.M., Ed., Applied Photosynthesis, Intech, Rijeka, 257-280.

[12] Santos, H.G., Jacomine, P.K.T., Anjos, L.H.C., Oliveira, V.A., Oliveira, J.B., Coelho, M.R., Lumbreras J.F. and Cunha, T.J.F. (2006) Sistema brasileiro de classificação de solos. Embrapa Solos, Rio de Janeiro, 306 p.

[13] Adati, C., Oliveira, V.A. and Karam, D. (2006) Mathematical and Biological Analysis of the Models For Estimating Culture Yield Losses Due to Weed Interference. Planta Daninha, 24, 1-12. http://dx.doi.org/10.1590/S0100-83582006000100001

[14] Kraemer, A.F., Marchesan, E., Avila, L.A., Machado, S.L.O. and Grohs, M. (2009) Environmental Fate of Imidazolinone Herbicides-A Review. Planta Daninha, 27, 629-639. http://dx.doi.org/10.1590/S0100-83582009000300025

[15] Pinto, J.J.O., Noldin, J.A., Pinho, C.F., Rossi, F., Galon, L. and Almeida, G.F. (2009) Field Persistence of (Imazethapyr + Imazapic) to Grain Sorghum (Sorghum bicolor) Planted in Rotation after Irrigated Rice. Planta Daninha, 27, 1015-1024.

[16] Sousa, C.P., Bacarin, M.A. and Pinto, J.J.O. (2012) Growth of Residual Herbicide (Imazethapyr + Imazapic) Bio-Indicators Sown in Rotation with Clearfield ${ }^{\circledR}$ Rice. Planta Daninha, 30, 105-111.

[17] Villa, S.C.C., Marchezan, E., Massoni, P.F.S., Santos, F.M., Avila, L.A., Machado, S.L.O., and Telo, G.M. (2006) Red Rice Control in Two Rice (Oryza sativa) Genotypes Tolerant to Imidazolinone Herbicides. Planta Daninha, 24, 549555.

[18] Avila, L.A., Massey, J.H., Senseman, S.A., Armbrust, K.L., Lancaster, S.R., Mccauley, G.N. and Chandler, J.M. (2006) Imazethapyr Aqueous Photolysis, Reaction Quantum Yield, and Hydroxyl Radical Rate Constant. Journal of Agricultural and Food Chemistry, 54, 2635-2639. http://dx.doi.org/10.1021/jf052214b

[19] Marchesan, E., Santos, F.M., Grohs, M., Avila, L.A., Machado, S.L.O., Senseman, S.A., Massoni, P.F.S. and Sartori, G.M.S. (2010) Carryover of Imazethapyr and Imazapic to Nontolerant Rice. Weed Technology, 24, 6-10.

[20] Silva, A.A., Vivian, R. and Oliveira Jr., R.S. (2007) Herbicidas: Comportamento No Solo. In: Silva, A.A. and Silva, J.F. Eds., Tópicos em manejo de plantas daninhas, Universidade Federal de Viçosa (UFV), Viçosa, 189-248. 